\title{
PELATIHAN PENGUKURAN STATUS GIZI BALITA DENGAN MENGGUNAKAN ANTROPOMETRI SEBAGAI UPAYA PENCEGAHAN STUNTING SEJAK DINI PADA IBU DI DARAT SAWAH SEGINIM BENGKULU SELATAN
}

\author{
Liya Lugita Sari \\ Universitas Dehasen Bengkulu \\ Email korespondensi : liyalugitasari@unived.ac.id \\ Disubmit: 28 Oktober $2021 \quad$ Diterima: 12 Desember $2021 \quad$ Diterbitkan: 02 Januari 2022 \\ DOI: https://doi.org/10.33024/jkpm.v1i1.5397
}

\begin{abstract}
ABSTRAK
Desa Darat Sawah Seginim adalah salah satu Desa yang memiliki jumlah balita yang banyak di Kabupaten Bengkulu Selatan, dan dapat menyumbangkan kejadian stunting di Kabupaten Bengkulu Selatan. Sebagai orang tua, dalam memberikan asuhan pertama untuk anak harusnya memiliki pengetahuan yang memadai dalam mengukur pertumbuhan dan perkembangan anak dengan menggunakan metode antropometri sederhana. Tujuan dari kegiatan ini adalah meningkatkan keterampilan ibu dalam pencegahan stunting sejak dini. Metode yang dilakukan adalah gabungan dari Penyuluhan untuk memberikan pengetahuan, pelatihan serta simulasi dimana Ibu hamil dan ibu yang mempunyai balita dikumpulkan dan diberikan pre-tes mengenai stunting, kemudian peneliti memberikan materi dan pelatihan pengukuran status gizi balita terhadap ibu hamil dan ibu yang mempunyai balita, setelah itu dilakukan post-tes untuk mengevaluasi kinerja pelatihan yang dilakukan. Hasilnya didapatkan Tingkat pengetahuan ibu-ibu setelah dilakukan pelatihan mengalami peningkatan sebesar $25 \%$ dengan rata-rata nilai adalah 80 dengan nilai rata-rata pada saat pretes yaitu 55. Saran pada kegiatan ini adalah memotivasi ibu-ibu untuk bisa menerapkan pengukuran antropometri dirumah dan bisa mengajarkan lagi kepada orang-orang disekitarnya.
\end{abstract}

Kata Kunci : Pelatihan, Status Gizi, Stunting

\begin{abstract}
Seginim Village is one of the villages that has a lot of children under five in South Bengkulu Regency, and can contribute to stunting in South Bengkulu Regency. As a parent, in providing first care for children, you should have adequate knowledge in measuring the growth and development of children using simple anthropometric methods. The purpose of this training activity is to improve the skills of mothers in early detection of stunting independently by using the anthropometric method. The method used is a combination of counseling to provide knowledge, training and simulations where pregnant women and mothers with toddlers are collected and given a pre-test regarding stunting, then the researchers provide material and training on measuring the nutritional status of toddlers to pregnant women and mothers who have toddlers, After that, a post-test was conducted to evaluate the performance of the training carried out. It is hoped that through this activity it can increase the
\end{abstract}


awareness of parents and pregnant women to prevent stunting. The result is that the level of knowledge of mothers after the training has increased with an average value of 80 . Suggestions in this activity are to motivate mothers to be able to apply anthropometric measurements at home and be able to teach again to the people around them.

Keywords: Training, Nutritional Status, Stunting

\section{PEDAHULUAN}

Stunting merupakan masalah gizi yang pada balita dan merupakan permasalahan nasional. Anak yang menderita stunting lebih rentan menderita penyakit dan beresiko mengidap penyakit degeneratih Ketika dewasa. Stunting mempengaruhi tingkat kecerdasan anak, padahal anak merupakan asset bangsa dimasa depan untuk mencegah hal tersebut pemerintah telah merencanakan program-program intervensi terdapat pencegahan stunting cesara terintegrasi yang melibatkan lintas Lembaga bahkan kementerian (Pusdatin, 2018).

Unicef menjelaskan bahwa prevalensi kejadian stunting pada anak dibawah 5 tahun di dunia mengalami penurunan dari tahun 2000 sebanyak 33,1 $\%$ menjadi 22,0 \% ditahun 2020 tetapi masih kurang untuk mencapai target pada tahun 2030 (Unicef, 2021). Berdasarkan Riset Kesehatan Dasar (Riskesdas) 2018 mencatat angka kejadian stunting Di Bengkulu Sebesar 27,98 persen, dimana 1 dari 3 anak di Bengkulu menderita stunting. Kasus stunting terbesar di Seluma sebanyak 35,91\%, Kaur 34,26\%, Bengkulu Selatan 33,73 \% dan Bengkulu Utara $26,81 \%$ dan empat kabupaten ini menjadi prioritas penanganan dalam penurunan stunting (BKKBN Bengkulu, 2021).

Stunting adalah kondisi gagal tumbuh pada anak balita yang disebabkan kekurangan gizi kronis. Kondisi gagal tumbuh disebabkan karna kurangnya asupan gizi dalam waktu lama dan bisa diakibatkan terjadinya infeksi berulang. Oleh sebab itu diperlukan pemenuhan gizi terutama dalam 1.000 hari pertama kehidupan (HPK). Anak dikatakan stunting apabila Panjang atau tinggi badan menurut umur lebih rendah dari standar nasional (Bapenas, 2018)

Selama kehamilan apabila seorang ibu mengkonsumsi asupan gizi yang rendah dan mengalami penyakit infeksi maka ibu tersebut akan melahirkan bayi dengan berat lahir rendah (BBLR) dan panjang badan dibawah standar. Pola asuh dan asupan gizi berpengaruh terhadap gizi anak dengan memberikan Asi Eksklusif dan pemberian makanan pendamping ASI (MP-ASI) secara tepat, selain itu akses air bersih dan sanitasi yang layak juga berpengaruh terhadap kejadian infeksi pada anak. Selain itu stunting juga dipengaruhi oleh beberapa faktor yaitu pendapatan, kesenjangan ekonomi, pedagangan, urbanisasi, globalisaasi, sistem pangan, jaminan social, sistem Kesehatan, dan pemberdayaan perempuan (Bapenas, 2018).

Ibu hamil dengan konsumsi asupan gizi yang rendah dan mengalami penyakit infeksi akan melahirkan bayi dengan Berat Lahir Rendah (BBLR), dan/atau panjang badan bayi di bawah standar. Asupan gizi yang baik tidak hanya ditentukan oleh ketersediaan pangan di tingkat rumah tangga tetapi juga dipengaruhi oleh pola asuh seperti pemberian kolostrum (ASI yang pertama kali keluar), Inisasi Menyusu Dini (IMD), pemberian ASI eksklusif, dan pemberian Makanan Pendamping ASI (MP-ASI) secara tepat. Selain itu, faktor kesehatan lingkungan seperti akses air bersih dan sanitasi layak serta pengelolaan sampah juga berhubungan erat dengan kejadian infeksi penyakit menular pada anak. Penyebab tidak langsung masalah stunting dipengaruhi oleh berbagai faktor, 
meliputi pendapatan dan kesenjangan ekonomi, perdagangan, urbanisasi, globalisasi, sistem pangan, jaminan sosial, sistem kesehatan, pembangunan pertanian, dan pemberdayaan perempuan(Bapenas, 2018).

Target prevalensi stunting pada Balita untuk tahun 2020 adalah 24,1\% (5.543.000 Balita), sementara laporan ePPGBM SIGIZI (per tanggal 20 Januari 2021) dari 34 provinsi menunjukkan bahwa dari 11.499.041 balita yang diukur status gizinya berdasarkan tinggi badan menurut umur (TB/U) terdapat 1.325.298 balita dengan TB/U <-2 SD atau dapat dikatakan 11,6\% balita mengalami stunting. (Laporan Kinerja). Di Seginim Kabupaten Bengkulu Selatan merupakan salah satu wilayah yang memiliki jumlah penduduk terbanyak ke-2 di Kabupaten Bengkulu Selatan dengan jumlah penduduk sebesar 16.061 Jiwa dan tentunya memiliki Balita yang banyak Pula serta menyumbang angka kejadian Stunting di Indonesia (Bengkulu Selatan, 2020).

\section{MASALAH}

Permasalahan yang dihadapi oleh masyarakat umum, khususnya orang tua yaitu pertama, kurangnya pengetahuan tentang pentingnya pemenuhan gizi seimbang bagi anak di masa pertumbuhan dan dan kurangnya kesadaran orang tua untuk melakukan pemantauan tumbuh kembang anak melalui pemeriksaan antropometri serta kurangnya pengetahuan ibu hamil mengenai status gizi. kurangnya kesadaran ibu hamil dan orang tua untuk memantau status gizi balita juga menjadi sebab pendukung tingginya angka kasus stunting, padahal dalam PP No 2 tahun 2020 pemeriksaan Antropometri sangat diperlukan karna pentingnya untuk mendeteksi dini risiko gagal tumbuh secara dini dan segera dilakukan tatalaksana segera (Indonesia, 2012).

Dalam penelitian yang dilakukan Ni wayan Eka (2019) menyatakan bahwa terdapat pengaruh pelaksanaan kelas ibu hamil untuk meningkatkan pengetahuan terhadap pencegahan stunting (Dian, 2019) oleh sebab itu diperlukannya keikut sertaan ibu hamil dalam pelatihan pengukuran status gizi ini sehingga ibu hamil tersebut dapat mempersiapkan tumbuh kembang anaknya dengan baik.

Hasil survey menunjukkan sebagian besar ibu di Seginim adalah Bertani sehingga terbenturnya waktu untuk ke posyandu dan pola pikir masyarakat hanya pergi ke posyandu apabila anak mau imunisasi saja, sedangkan kalau tidak lagi di imunisasi maka tidak perlu lagi ditimbang atau dipantau tumbuh kembangnya ke posyandu kembali. Beberapa upaya telah dilakukan oleh Pemerintah termasuk petugas kesehatan guna menekan angka kejadian stunting di Desa Seginim, antara lain pengembangan posyandu, pelatihan kader, dan melakukan advokasi kepada stakeholder setempat guna mendapatkan dukungan. Namun demikian, upaya tersebut belum membuahkan hasil yang maksimal, hal ini dikarenakan kurangnya pelatihan-pelatihan yang mengikut sertakan masyarakat terutama

Maka diperlukan suatu kegiatan atau aktivitas yang bertujuan untuk meningkatkan keterampilan masyarakat dalam deteksi dini kejadian stunting. Masyarakat perlu diberikan pelatihan pengukuran status gizi balita secara mandiri dirumah, salah satunya dengan menggunakan metode antropometri. Pengukuran status gizi secara antropometri ini menggunakan alat sederhana, seperti timbangan dan meterline. Selain itu juga dapat dipantau melalui pertumbuhan berat badan dan tinggi badan sesuai usia balita. Apabila orang tua dapat melakukan pengukuran status gizi balita dirumah secara mandiri, harapannya dapat menjadi langkah awal pencegahan stunting sejak dini. 


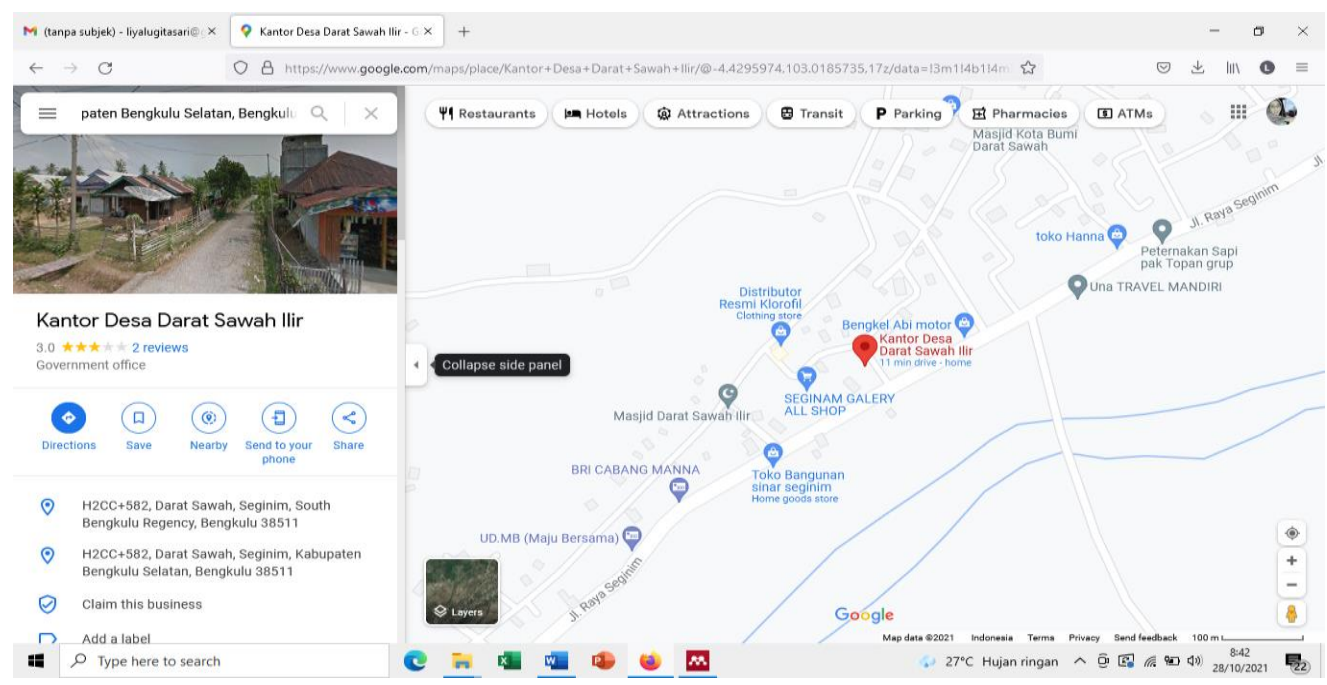

Gambar 1 peta lokasi puskesmas kegiatan

\section{METODE}

a. Tujuan Persiapan

Kegiatan ini yang dilakukan dengan menggunakan tiga metode yaitu:

1) Penyuluhan sebagai upaya mengawali proses pelatihan bertujuan untuk menghasilkan pengetahuan dasar untuk peserta terhadap ketrampilan dan peran orang tua dalam pengukuran status gizi balita. Materi pendidikan masyarakat atau penyuluhan bermuatan utama terkait gambaran Permasalahan stunting di Indonesia pengertian stunting dan pengukuran status gizi dengan metode Antropometri.

2) Pelatihan sebagai upaya lanjutan dalam proses pelatihan yang bertujuan untuk meningkatkan kecakapan atau ketrampilan orang tua.

3) Metode simulasi mengenai keterampilan orang tua dalam mengukur status gizi balita yang diperoleh melalui proses penyuluhan yang dan pelatihan atau praktik yang dilakukan sebelumnya, simulasi yang dilakukan disini yaitu orang tua/ibu hamil melakukan pengukuran tinggi ,berat badan balita,lingkar kepala, dan lingkar Lengan atas balita.

Tahap persiapan dari kegiatan yaitu pembuatan Pre Planning, Persiapan Penyajian Materi Berupa Power Point serta Timbangan, pengukur Tinggi badan dan Meteran dan alat-alat tersebut disiapkan di kantor Desa Darat Sawah. Pembuatan Materi dilakukan tanggal 13 Oktober 2021 dan pada tanggal 19 Oktober dilakukan Pengecekan untuk persiapan Penyuluhan, Pelatihan dan simulasi Pengukuran Status Gizi Balita sehingga acara dapat berlangsung dengan baik nantinya.

b. Tahap Pelaksanaan

Acara ini dilaksanakan dengan bantuan kepala desa untuk memberitahukan warganya yaitu ibu hamil dan ibu yang mempunyai balita untuk berkumpul di ruangan serba guna Kantor Desa Darat Sawah,untuk selanjutnya diberikan pelatihan. Adapun tahapan pelaksanaan Acara Pengabdian Masyarakat Ini dalah 
1) Sambutan dari Sekertaris Desa

2) Pre tes untu Menggali Sejauh mana pengetahuan ibu mengenai pengukuran antropometri dan status gizi anak, hasil pretes didapatkan rata-rata nilai pengetahuan audiens mengenai pengukuran status gizi menggunakan pemeriksaan antropometri dalam upaya penurunan stunting yaitu 50

3) Penyampaian Materi mengenai pengukuran status gizi balita sebagai upaya pencegahan stunting sejak dini pada ibu di darat sawah seginim bengkulu selatan

4) Melakukan pelatihan cara untuk mengukur Antropometri Untuk mengukur Status Gizi Balita

5) Simulasi yang dilakukan oleh Masyarakat dan dibimbing oleh Pemateri

6) Post tes untuk mengevaluasi pelaksanaan pelatihan yang dilakukan

c. Evaluasi

1) Struktur

Peserta yang hadir sebanyak 15 orang yang terdiri dari 5 orang ibu hamil dan 10 orang ibu yang mempunyai balita. Setting tempat tidak sesuai dengan rencana dikarenakan mendadak dipakai untuk acara lain. Sedangkan perlengkapan yang digunakan sudah sesuai denga napa yang sudah direncanakan. Audiens yaitu Ibu hamil dan Ibu yang mempunyai balita memahami materi yang disampakian oleh Pemateri dan penyampaian materi menggunakan Bahasa Indonesia dan Bahasa Daerah. Setelah dilakukan post test mengenai pelatihan dilakukan didapatkan rerata nilai audiens yaitu 80 .

2) Proses

Pelaksanaan kegiatan dilakukan pada tanggal 20 Oktober 2021 pukul 08.00-11.00 WIB, dan sesuai dengan jadwal yang telah ditentukan sebelumnya.

\section{HASIL DAN PEMBAHASAN}

Metode pelaksaanaan Kegiatan dilaksanakan di Puskesmas Darat Sawah Seginim dan dilaksanakan pada tanggal 5 Otober 2021 ini diikuti oleh ibu yang memiliki balita serta ibu hamil di Darat Sawah Seginim Bengkulu Selatan kegiatan pengabdian ini karena lokasi Darat Sawah Seginim bengkulu selatan memiliki banyak balita dan untuk mengetahui tingkat pengetahuan peserta dalam menjaga anak agar tidak terkena stunting dan diberikan materi tentang pengukuran status gizi balita. Adapaun media dan alat yang digunakan yaitu power Point untuk penyuluhan serta Timbang Berat Badan, Pengukur Tinggi badan dimana hal ini mengacu dalam PP No.2 tahun 2020 mengenai standar Antropometri Anak, dimana dapat dilakukan Penimbangan berat badan, Panjang/tinggi badan serta Indeks Massa Tubuh, tetapi dalam kegiatan ini hanya dilakukan pelatihan pengukuran BB dan TB untuk menilai status Gizi anak tersebut dan anak tersebut menderita stunting atau tidak (Menteri Kesehatan Republik Indonesia, 2020). Sebelum memulai penyuluhan peserta diberikan pretest mengenai stunting dan pemeriksaan antropometri, dan didapatkan hasil rata-rata pengetahuan peserta yaitu 55 . Selanjutnya dilakukan tahap-tahap kegiatan yaitu 
a. Penyuluhan

Peserta diberikan edukasi berupa materi tentang pengukuran status gizi balita pemberian materi ini dimaksudkan untuk menunjang pengetahuan peserta adalah sebagai berikut

1) Data Kejadian stunting di Indonesia dimana 11,6\% balita mengalami stunting dan bengkulu selatan merupakan kabupaten ke3 terbanyak menderita stunting (Bengkulu Selatan, 2020)

2) Definisi stunting adalah suatu kondisi dimana balita memiliki panjang atau tinggi badan yang tidak sesuai dengan umur (Kemenkes, 2018).

3) Penyebab stunting dalam bulletin situasi balita pendek (Stunting) di Di Indonesia, penyebab stunting adalah kekurangan gizi kronik di mulai dari kehamilan sampai balita, selain itu diakibatkan oleh kondisi social ekonomi, kesakitan pada bayi sehingga balita akan mengalami kesulitan dalam mencapai perkembangan fisik dan kognitif yang optimal.(Kemenkes, 2018)

4) Dampak stunting. Dampak yang akan terjadi pada balita dibagi menjadi dampak jangka pendek dan jangka Panjang, yaitu Jangka pendek

a) Terjadinya peningkatan kesaakitan dan kematian

b) Kurang optimalnya perkembangan anak baik perkembangan kognitif, motoric dan verbal

c) Peningkatan biaya untuk Kesehatan Jangka Panjang

a) Lebih pendek dibandingkan balita pada umumnya

b) Meningkatnya resiko obesitas dan penyakit penyerta lain

c) Kesehatan reproduksi yang menurun

d) Kurang optimal dalam kapasitas belajar

e) Produktifitas kurang optimal (Pusdatin, 2018).

5) Pencegahan stunting dengan pengukuran status gizi balita. Menurut Kemenkes dengan melakukan pemantauan tumbuh kembang anak, terutama tinggi dan berat badan secara berkala akan lebih mudah bagi ibu untuk mengetahui gangguan gizi dan dapat dilakukan penangan segera (Kemeterian Kesehatan Republik Indonesia, 2019).

6) Cara pengukuran status gizi balita secara mandiri

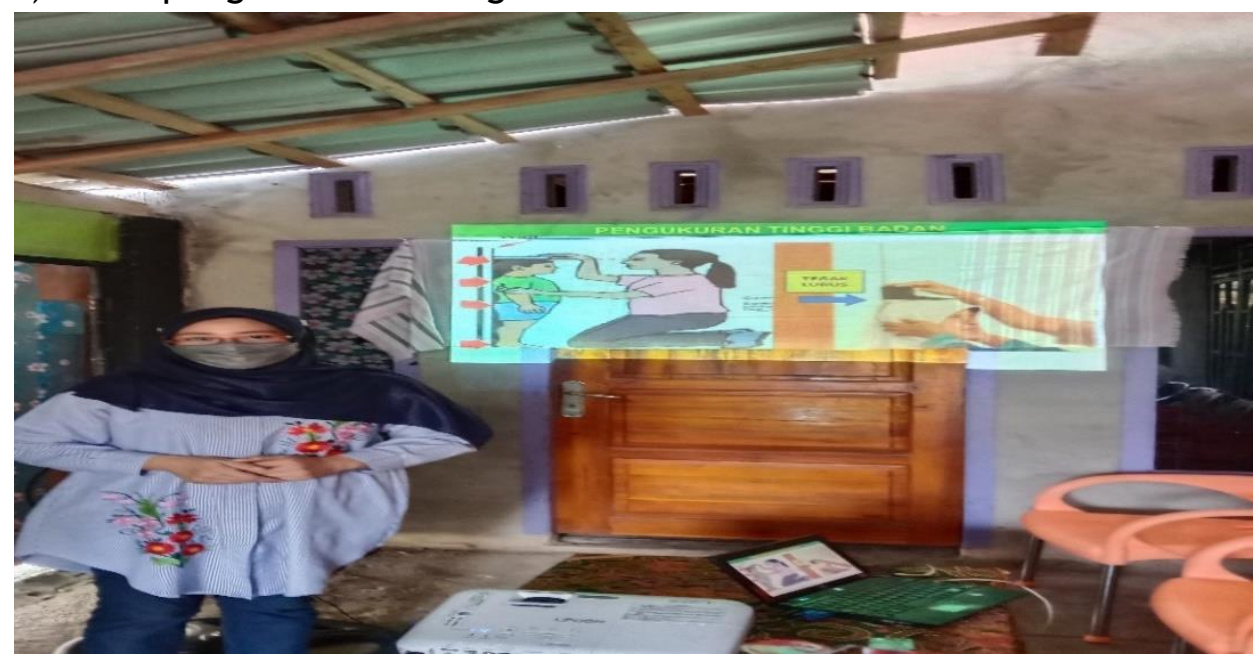

Gambar 2 Penyuluhan Pengukuran Status Gizi 
b. Pelatihan

Tahap ini dilakukan setelah diberikan materi edukasi. Kegiatan ini dilakukan untuk memaksimalkan pengetahuan peserta mengenai pengukuran Status gizi melalui Pemeriksaan Antropometri.

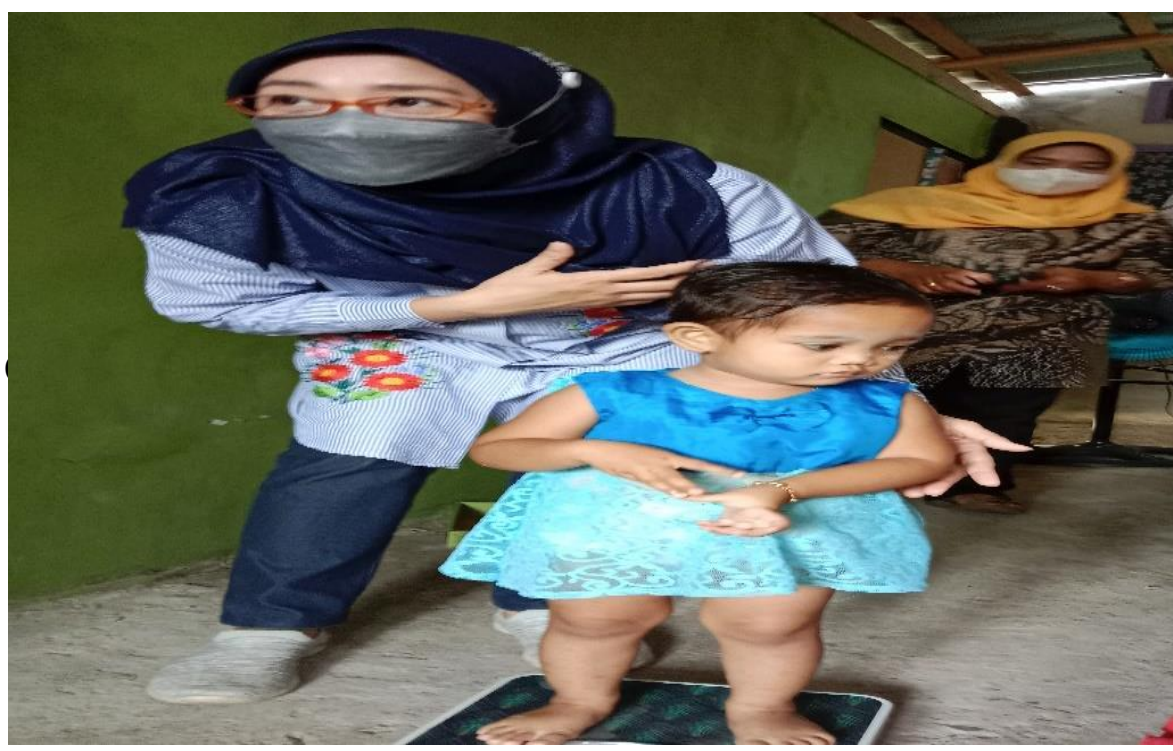

Gambar (2) pengukuran Berat Badan Balita

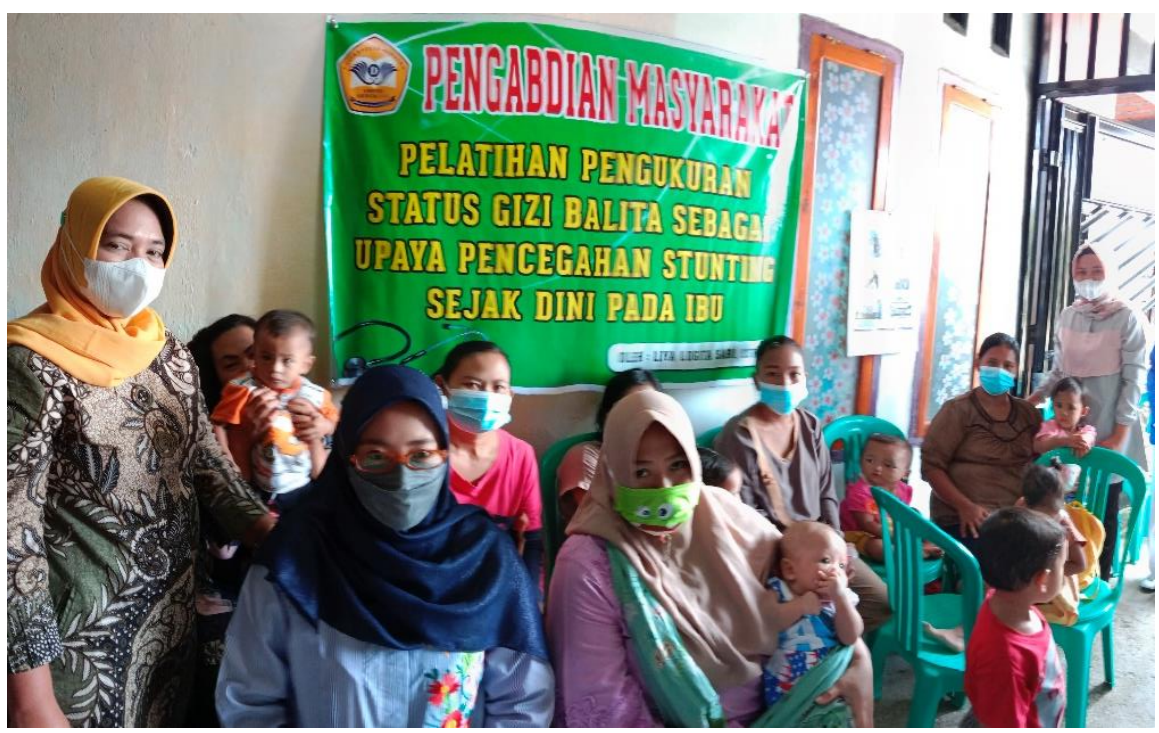

Gambar (3) Peserta Pelatihan

\section{KESIMPULAN}

Kegiatan pelatihan pengukuran status gizi balita telah meningkatkan pengetahuan pada ibu dan perserta didukung dengan keterampilan perserta melalui metode pelatihan dan simulasi dapat memberikan kontribusi positif dalam mengurangi dan mencegah kasus stunting di indonesia khusunya wilayah bengkulu selatan seginim. 


\section{DAFTAR PUSTAKA}

Bapenas. (2018). pedoman pelaksanaan intervensi penurunan stunting terintegrasi di kabupaten/ kota. http://tnp2k.go.id/filemanager/files/Rakornis 2018/Pedoman Pelaksanaan Intervensi Penurunan Stunting Terintegrasi Di Kabupaten Kota.pdf

Bengkulu Selatan, D. (2020). Profil Kesehatan Dinas Kesehatan tahun 2019.

BKKBN Bengkulu. (2021). Satu Dari Tiga Anak di Bengkulu Menyandang Stunting. BKKBN. http://bengkulu.bkkbn.go.id/?p=3387

Dian, N. (2019). Edukasi Gizi pada Ibu Hamil Mencegah Stunting pada Kelas Ibu Hamil. Jurnal Kesehatan, 10(3), 312-319. https://ejurnal.poltekkestjk.ac.id/index.php/JK/article/view/1389/1032

Indonesia, P. R. (2012). PERATURAN PEMERINTAH REPUBLIK INDONESIA NOMOR 33 TAHUN 2012 TENTANG PEMBERIAN AIR SUSU IBU EKSKLUSIF. http://hukor.kemkes.go.id/uploads/produk_hukum/PP No. 33 ttg Pemberian ASI Eksklusif.pdf

Kemenkes. (2018). Situasi Balita pendek (Stunting) di Indonesia. Pusat Data dan Informasi Kementerian Kesehatan Republik Indonesia. https: / pusdatin.kemkes.go.id/folder/view/01/structure-publikasipusdatin-buletin.html

Kemeterian Kesehatan Republik Indonesia. (2019). Pencegahan Stunting Pada Anak. Direktorat Promosi Kesehatan Dan Pemberdayaan Masyarakat. ttps://promkes.kemkes.go.id/pencegahan-stunting

Menteri Kesehatan Republik Indonesia. (2020). Peraturan menteri Kesehatan Republik Indonesia Nomor 2 Tahun 2020 Tentang Standar Antropometri. http://hukor.kemkes.go.id/uploads/produk_hukum/PMK_No_2_Th_2020_ ttg_Standar_Antropometri_Anak.pdf

Pusdatin. (2018). Situasi balita pendek (stunting) di Indonesia. https: / / pusdatin.kemkes.go.id/article/view/18102500001/situasi-balitapendek-di-indonesia.html

Unicef.

Malnutrition. https://data.unicef.org/topic/nutrition/malnutrition/

Zainaro, M. A., Dherlirona, D., \& Norabela, A. (2018). Hubungan Kualitas Pelayanan Kesehatan Dengan Kepuasan Pasien Di Klinik Dira Medika Gotong Royong Bandar Lampung Tahun 2017. Holistik Jurnal Kesehatan, 12(2), 126135. 